\title{
Human neutrophil activating peptide/interleukin 8 acts as an autoantigen in rheumatoid arthritis
}

\author{
P Peichl, M Ceska, H Broell, F Effenberger, I J D Lindley
}

\begin{abstract}
Human neutrophil activating peptide/interleukin 8 (NAP-1/IL-8) has been shown to activate neurophils to degranulate in vitro and to be a potent chemotactic agonist for neutrophils and lymphocytes in vitro and in vivo. It may therefore be a mediator of inflammatory conditions such as rheumatoid arthritis (RA).

Levels of NAP-1/IL-8 were low or undetectable in serum samples from 53 patients with RA. Circulating levels of antibodies to NAP-1/IL-8 showed a strong correlation with the level of quantified $\mathbf{C}$ reactive protein and with the number of arthritic joints. These autoantibodies, in a similar manner to quantified C reactive protein, correlated with disease activity and are associated with a lack of clinical improvement when the patient is treated with systemic steroids.

This observation indicates an important role for interleukin 8 and its autoantibodies in the inflammatory processes of RA, and may provide a clinically useful marker for the diagnosis of disease severity.
\end{abstract}

Human neutrophil activating peptide/interleukin 8 (NAP-1/IL-8) is a 72 amino acid peptide which has been shown to activate neutrophils to degranulate and show respiratory burst in vitro, ${ }^{12}$ and to be chemotactic for neutrophils and lymphocytes in vitro and in vivo. ${ }^{3-6}$

Neutrophils are a major source of enzymes, including those which degrade cartilage, ${ }^{7}$ and the accumulation of these cells in tissues is often observed in a variety of pathological conditions. These observations led us to examine circulating levels of the cytokine and antibodies directed against it in patients with rheumatoid arthritis (RA), and the development of a solid phase double ligand enzyme linked immunosorbent assay, ${ }^{8}$ (ELISA) has enabled quantitative determinations of these parameters in serum samples.

Serum samples from 53 patients with definite or classical RA as defined by the American Rheumatism Association criteria ${ }^{9}$ were tested for NAP-1/IL-8 and antibodies to NAP-1/ IL-8. The clinical examinations were performed by a single observer.

The assay results were correlated with levels of quantified $\mathrm{C}$ reactive protein and with the number of arthritic joints, characterised by inflammation, pain, stiffness, swelling, and impairment. The levels of $\mathrm{C}$ reactive protein provide an objective index of disease activity in patients with RA, as high levels are associated with progressive disease, whereas the induction of clinical remission and control of the underlying disease process is associated with prompt normalisation of the level of $\mathrm{C}$ reactive protein.

\section{Methods}

Quantified C reactive protein was determined by the standard nephelometric method of Whicher $e t$ al. ${ }^{10}$

Goat polyclonal and mouse monoclonal antibodies to NAP-1/IL-8 were purified by immunosorption on a recombinant NAP-1/ IL-8-Sepharose column. The two types of antibody bind to NAP-1/IL-8 in Western blots, showing a strong band at 8.5 kilodaltons, and both inhibit NAP-1/IL-8 induced elastase release from freshly isolated human neutrophils (data not given).

NAP-1/IL-8 was determined by a solid phase double ligand ELISA with a quantitative evaluation range of $0 \cdot 2-25 \mathrm{ng} / \mathrm{ml} .{ }^{8}$ Briefly, wells of microtitre plates were coated with immunosorbent purified polyclonal goat or mouse monoclonal antibodies to NAP-1/IL-8 in $0.1 \mathrm{M}$ sodium carbonate/sodium hydrogen carbonate buffer ( $\mathrm{pH} \mathrm{9.6)} \mathrm{for} 16$ hours at $4^{\circ} \mathrm{C}$. After four washes with phosphate buffered saline $(\mathrm{pH}$ $7 \cdot 5$ ), the serum samples were added to the wells and incubated for two hours at $37^{\circ} \mathrm{C}$. After four washes, goat anti-NAP-1 alkaline phosphatase conjugate was added and the plates were incubated for a further two hours at $37^{\circ} \mathrm{C}$. After the addition of $p$-nitrophenyl phosphate and incubation the reaction was terminated by the addition of $2 \mathrm{M}$ sodium hydroxide solution and the absorption measured at $\mathbf{4 0 5} \mathrm{nm}$. The bound NAP-1 was determined by comparison with a standard.

To define the specificity of this ELISA we tested several peptides with high homology to NAP-1/IL-8 for cross reactivity. At concentrations up to $1000 \mathrm{ng} / \mathrm{ml}$, connective tissue activating peptide 3 , platelet factor 4 , and neutrophil activating peptide 2 show no cross reactivity with NAP-1/IL-8 (data not given).

Circulating antibodies to NAP-1/IL-8 were determined by a similar method, in which the wells of microtitre plates were coated with NAP-1/IL-8 at a concentration of $5 \mu \mathrm{g} / \mathrm{ml}$ and stored overnight at $4^{\circ} \mathrm{C}$. The wells were then washed four times with $0.05 \%$ Tween 20 , and $100 \mu \mathrm{l}$ amounts of serum samples (diluted 1:10) were added and incubated at $37^{\circ} \mathrm{C}$ for two hours. After four washings, $50 \mu$ l of goat antihuman IgG alkaline phosphatase conjugate (Bio-Rad) was added at a concentration of $5 \mu \mathrm{g} / \mathrm{ml}$ and the plates again incubated for two 
hours at $37^{\circ} \mathrm{C}$. The enzymatic reaction was initiated by the addition of $p$-nitrophenyl phosphate as before, and the absorption was determined at $405 \mathrm{~nm}$ after termination of the reaction with $2 M$ sodium hydroxide solution. As no standard human IgG antibody to IL-8 is available, the absolute concentrations could not be defined. Antibody levels are therefore expressed as density units from the ELISA to give values of relative concentration. The antibodies in serum samples, which recognise the purified recombinant NAP-1/IL-8 bound to the plate, also recognise the bound NAP-1/ IL-8 on the immunosorbent column, and can be quantitatively removed from the serum sample on this column.

Regression analysis of the results was performed with the RS1 statistics programme from BBN Software Products.

Lipopolysaccharides were determined by an automated system. ${ }^{11}$

\section{Results}

Table 1 gives the age, sex, disease stage, and treatment of the studied patients. Of 53 serum
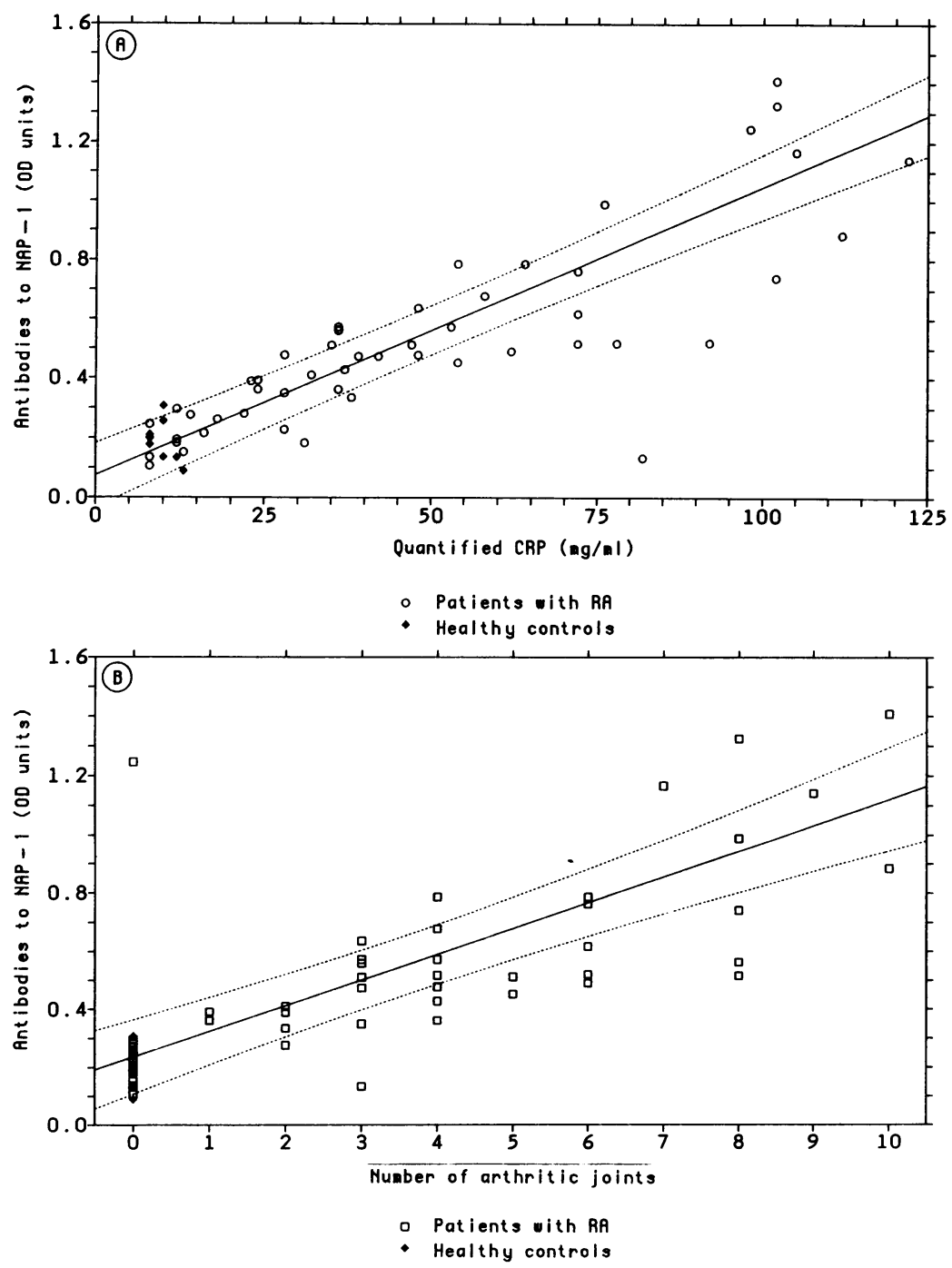

Figure 1 Relationship between levels of IgG antibodies to NAP-I/IL-8 in serum samples and $(A)$ quantified $C$ reactive protein or $(B)$ number of arthritic joints. Points represent individual patients. Antibody levels are given as units of absorption at $405 \mathrm{~nm}\left(O D_{405}\right)$ from the ELISA (see under Methods). Dotted lines represent $95 \%$ confidence limits.
Table 1 Age, sex, disease stage; and treatment of patients included in this study. Figures given for disease stage and treatment are numbers of patients

\begin{tabular}{ll}
\hline Mean age in years (range) & $54 \cdot 2(27-82)$ \\
Sex (women/men) & $33 / 20$ \\
Mean duration of disease & \\
in years (range) & $6 \cdot 5(0 \cdot 6-24)$ \\
Disease status: & \\
Steinbrocker I & 21 \\
Steinbrocker II & 25 \\
Steinbrocker III & 6 \\
Steinbrocker IV & 1 \\
Rheumatoid factor positive/negative & $27 / 26$ \\
Treatment: & \\
Antimalarial drugs & 15 \\
Gold salts & 16 \\
D-Penicillamine & 5 \\
Steroid/ACTH & 11 \\
Immunosuppressive drugs & 17 \\
\hline
\end{tabular}

${ }^{*}$ ACTH=adrenocorticotrophic hormone.

samples, $14(26 \%)$ contained NAP-1/IL-8 at levels of $0 \cdot 27-4 \cdot 6 \mathrm{ng} / \mathrm{ml}$ and no significant difference in the levels was seen in samples taken 8 and 20 days later (data not given). There was no correlation between these low NAP-1/ IL-8 concentrations and disease severity. In all patients, irrespective of the NAP-1/IL-8 concentration, a low lipopolysaccharide concentration of approximately $10 \mathrm{pg} / \mathrm{ml}$ was found.

No NAP-1/IL-8 was found in serum samples from nine healthy controls, and these controls defined the background titre range of 0.089 0.307 absorption units for antibodies to NAP-1/ IL-8. These patients had low circulating levels of quantified $\mathrm{C}$ reactive protein between 8 and $13 \mathrm{mg} / \mathrm{l}$.

Similar background levels of antibodies to NAP-1 (0.106-0.296 absorption units) were detected in nine patients with RA who were either in complete remission or showing a significant improvement as a result of treatment. In patients with active disease, however, higher levels of antibody were detected. Figure 1 shows the highly significant relationship between levels of antibody to NAP-1 and quantified $C$ reactive protein (fig. $1 A$ ) and the number of arthritic joints in all patients (fig 1B). Table 2 gives the statistical correlations for these data. No significant correlation was seen between antibody levels and the duration of disease, and, similarly, there was no significant difference in titres of antibody to IL-8 between rheumatoid factor positive and negative patients.

Figure 2 shows the titres for IgG antibody to NAP-1/IL-8 in serum samples from the same patients divided into treatment groups. There is a tendency towards higher antibody levels in the patients treated with immunosuppressive drugs and D-penicillamine. These drugs are generally regarded as second line treatment, used for patients where the disease appears to be resistant to initial treatment with gold or

Table 2 Statistical correlations between IgG antibodies to NAP-1/IL-8, number of arthritic joints and quantified $C$ reactive protein. $p<0.001$

\begin{tabular}{lll}
\hline & $\begin{array}{l}\text { Quantified C } \\
\text { reactive protein }\end{array}$ & $\begin{array}{l}\text { No of } \\
\text { arthritic joints }\end{array}$ \\
\hline $\begin{array}{l}\text { Arthritic joints } \\
\text { Antibodies to } \\
\text { NAP-1/IL-8 }\end{array}$ & 0.859965 & \\
\hline
\end{tabular}




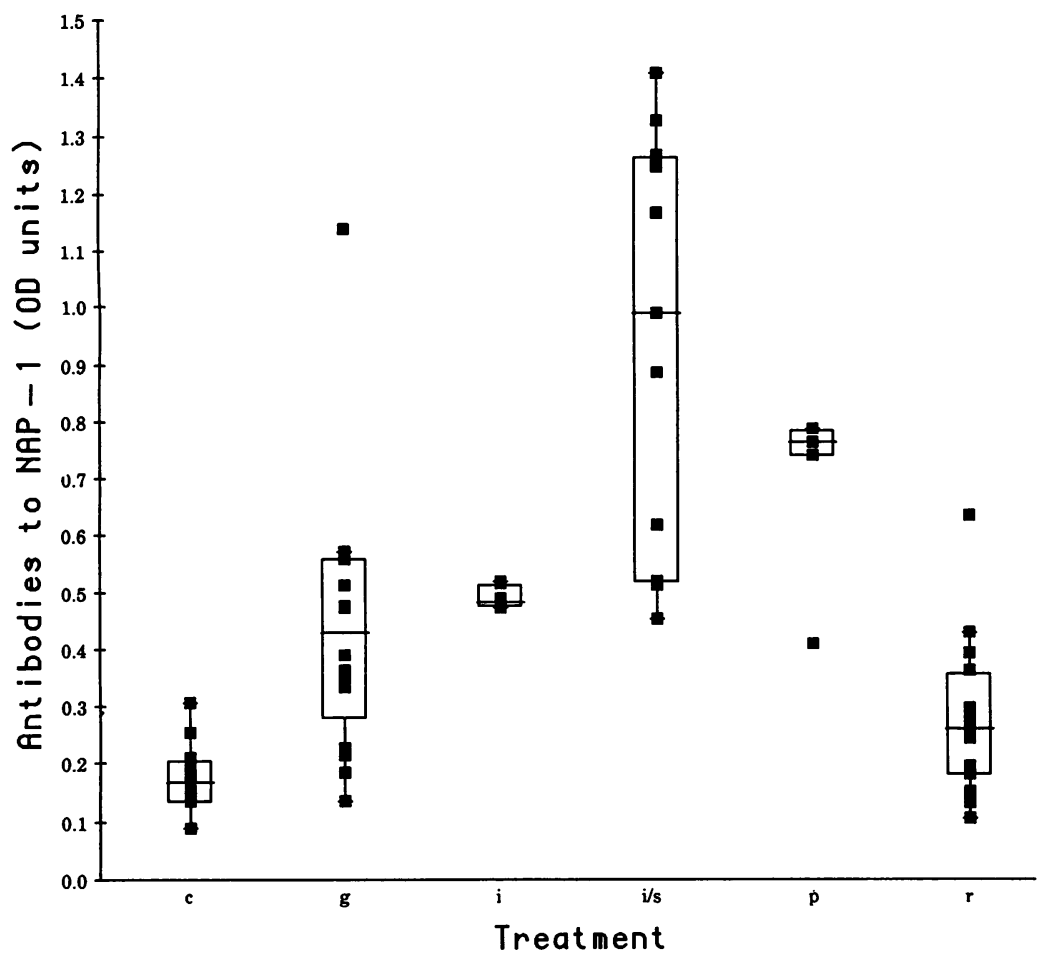

Figure 2 Levels of IgG antibodies to NAP-I/IL-8 in patients with $R A$ divided into treatment groups. (c) Normal control subjects $(\mathrm{n}=9)$. (g) Patients receiving $6 \mathrm{mg}$ auranofin daily by mouth $(\mathrm{n}=16)$. (i) Patients receiving immunosuppressive treatment $(\mathrm{n}=5)$; two received $25 \mathrm{mg}$ methotrexate weekly, and three received $100 \mathrm{mg}$ azathioprine daily. (i/s) Patients receiving immunosuppressive treatment plus steroids $(\mathrm{n}=11)$; three patients received $1 \mathrm{mg}$ ACTH (tetracosactid) weekly plus $25 \mathrm{mg}$ methotrexate weekly, eight received 8-20 methylprednisolone daily, of whom four also received $100 \mathrm{mg}$ azathioprine daily, and four received 25 mg methotrexate weekly. (p) Patients receiving penicillamine, $150-500 \mathrm{mg}$ daily $(n=5)$. ( $r$ ) Patients receiving treatment with Resochin; $250 \mathrm{mg}$ chloroquine daily $(\mathrm{n}=15)$. Points represent individual patients. Antibody levels are given as units of absorption at $405 \mathrm{~nm}\left(O D_{405}\right)$ from the ELISA (see under Methods). interleukin 1 have been reported in a small proportion (17\%) of patients with $\mathrm{RA},{ }^{15}$ and Fomsgaard et al have described antibodies directed against tumour necrosis factor in patients with various rheumatic diseases. ${ }^{16}$ These authors did not, however, show a correlation between antibody levels and disease severity, as is seen here.

The specific function of such circulating antibodies to cytokines is unclear. It has been speculated that they could represent a mechanism of cytokine regulation, acting as physiological carriers of the cytokine, or could fulfil an inhibitory role, neutralising unwanted activities. ${ }^{17}$ It is possible that such a regulatory influence could be applied to NAP-1/IL-8. This cytokine has the potential to play a major role in RA, as it appears to be produced at high concentrations in the affected joints of patients with RA. We have detected NAP-1/IL-8 in the synovial fluid of patients with $\mathrm{RA}$ at levels which correlate extremely well with disease severity, determined by either the concentration of quantified $\mathrm{C}$ reactive protein in serum samples, or the total cell count in the synovial fluid. ${ }^{18}$

NAP-1/IL-8 could be either a stimulator of the disease processes of RA, or a direct result of these processes. Its release from the affected joint would result in high levels of IL-8 in the circulation, followed by an increase in autoantibodies. This would explain why levels of antibody to NAP-1/IL-8 correlate with disease severity. The higher the titre, the stronger the treatment needed to induce remission or even to stabilise the disease, for these high titres are associated with a lack of clinical improvement under treatment with systemic steroids, and are indicative of a need for immunosuppressive treatment, or even combination treatment with immunosuppressive drugs and steroids.

These observations indicate an important role for IL-8 and its autoantibodies in the inflammatory processes of RA, and may provide a clinically useful marker for the diagnosis of disease severity.

\section{Discussion}

In the rheumatoid serum samples tested there was a clear correlation between the serological and clinical parameters indicative of disease and the presence of autoantibodies against IL-8. This observation, together with the low or undetectable IL-8 titres in patients with raised levels of quantified $C$ reactive protein and antibodies suggests a possible interaction between IL- 8 and its autoantibody, and could indicate a major role for IL-8 and antibodies to IL-8 in this disease.

Interleukin 1 and tumour necrosis factor are both potent stimulators of IL-8 production from a variety of cell types, ${ }^{7} 12$ possibly providing another fundamental link in the chain of reactions leading to inflammation. In RA generated by an immune response to an as yet unidentified antigen, the involvement of monocytes and lymphocytes and their secretion of inflammatory and chemotactic factors has been well documented. ${ }^{14}$

Reports of autoantibodies to cytokines are relatively rare, although titres of antibody to
We thank Dr Ekke Liehl and Professor Alain de Weck for critical discussion of the manuscript.

1 Peveri P, Walz A, Dewald B, Baggiolini M. A novel neutrophil-activating factor produced by human mononuclear phagocytes. F Exp Med 1988; 167: 1547-59.

2 Thelen M, Peveri P, Kernen P, von Tscharner V, Walz. A, Baggiolini $M$. Mechanism of neutrophil activation by $\mathrm{NAF}$, a novel monocyte-derived peptide agonist. FASEB $\mathcal{F}$ 1988; 2: 2702-6.

3 Lindley I, Aschauer H, Seifert J M, et al. Synthesis and expression in $E$. coli of the gene encoding monocytederived neutrophil-activating factor: biological equivalence derived neutrophil-activating factor: biological equivalence between natural and recombinant neutrophil-activatin
factor. Proc Natl Acad Sci USA 1988; 85: 9199-203.

4 Schroeder J M, Mrowietz U, Morita E, Christophers E. Purification and partial biochemical characterisation of a human monocyte-derived, neutrophil-activating peptide that lacks interleukin 1 activity. I Immunol 1987; 139: 3474-83.

5 Van Damme J, Van Beeumen J, Opdenakker G, Billiau A. A novel $\mathrm{NH}_{2}$-terminal sequence-characterised human monokine possessing neutrophil chemotactic, skin-reactive, monokine possessing neutrophil chemotactic, skin-reactive, 167: 1364-76.

6 Larsen C G, Anderson A O, Appella E, Oppenheim J J, Matsushima K. The neutrophil-activating protein (NAP-1) 1464-6.

7 Baggiolini M, Walz A, Kunkel S. Neutrophil-activating peptide $1 /$ interleukin 8 , a novel cytokine that activates neutrophils. F Clin Invest 1989; 84: 1045-9. is also chemotactic for $T$ lymphocytes. Science $1989 ; 243$ 
8 Ceska M, Effenberger F, Peichl P, Pursch E. Purification and characterisation of monoclonal and polyclonal antibodies to neutrophil activating peptide (NAP-1). The development
of highly sensitive ELISA methods for the determination of NAP-1 and anti-NAP-1 antibodies. 2nd International Workshop on Cytokines, 1989 Dec; Hilton Head (SC).

9 Ropes M W. Diagnostic criteria for rheumatoid arthritis. Ann Rheum Dis 1958; 18: 49-54.

10 Whicher J T, Bell A M, Southall P J. Inflammation measurements in clinical management. Diagnostic Medicine $1981 ; 4: 62-80$.

11 Seidl G, Malacek L. Application of laboratory robotics for the automation of the turbidometric LAL endotoxin assay. Laboratory Robotics and Automation 1989; 1: 215-25.

12 Elner V, Strieter R, Elner S, Baggiolini M, Lindley I, Kunkel S. Human retinal pigment epithelial cells produce neutrophil chemotactic factor in response to IL-1 and TNF- $\alpha$. Am F Pathol 1990; 136: 745-50.

13 Thornton A J, Strieter R M, Lindley I, Baggiolini M, Kunkel $S$ L. Cytokine-induced gene expression of a neutrophil chemotactic factor/interleukin-8 in human hepatocytes. 7 Immunol 1990; 144: 2609-13.

14 Kelly W, Harris E, Ruddy S, Sledge C, eds. Pathogenesis of RA. In: Textbook of rheumatology. Philadelphia: Saunders, 1985.

15 Suzuki H, Akama T, Okane M, et al. Interleukin-1-inhibitory IgG in sera from some patients with rheumatoid arthritis. Arthritis Rheum 1989; 32: 1528-38.

16 Fomsgaard A, Svenson M, Bendtzen K. Auto-antibodies to tumour necrosis factor in healthy humans and patients with inflammatory diseases and Gram-negative bacterial infections. Scand f Immunol 1989; 30: 219-23.

17 Bendtzen K, Svenson M, Jonsson V, Hippe E. Autoantibodies to cytokines-friends or foes? Immunol Today 1990; 11: 167-9.

18 Peichl P, Ceska M, Broell H, Effenberger F, Lindley I J D. Presence of NAP-1/IL-8 and anti-NAP-1/IL-8 in synovial fluids indicates a possible pathogenic role in rheumatoid arthritis. Scand f Immunol 1991; 34: 333-9. 